\title{
Inhibitory Effects of Soyasaponins on Antigen-induced Degranulation in RBL-2H3 Cells
}

\author{
Seung Hwan Yang $\cdot$ Jung A Lee $\cdot$ Jae Yeon Lee E Eun-Kyung Ahn Tai-Sun Shin • \\ Chigen Tsukamoto - Gyuhwa Chung* · Joo-Won Suh* ${ }^{1}$
}

\section{Soyasaponin의 RBL-2H3 세포에서 탈과립화 억제 효과}

양숭환 · 이정아·이재연 · 안은경·신태선·찌갱 쯔카모토·정규화* 서주원*

Received: 1 July 2015 / Accepted: 5 August 2015 / Published Online: 30 September 2015

(C) The Korean Society for Applied Biological Chemistry 2015

\begin{abstract}
Soyasaponins are glycosylated, which gives rise to a wide diversity of structures and functions. We evaluated for inhibitory effects of 4 soyasaponins on antigen-induced degranulation in RBL-2H3 Cells. 4 soyasaponins had shown dose-dependently inhibited histamine and $\beta$-hexosaminidase.
\end{abstract}

S. H. Yang and J. A. Lee contributed equally.

S. H. Yang $\cdot$ J.-W. Suh

Center for Nutraceutical and Pharmaceutical Materials, Myongji University, Yongin, Gyeonggi 449-728, Republic of Korea

J. A. Lee · J. Y. Lee $\cdot$ E.-K. Ahn

Bio-center, Gyeonggi Institute of Science and Technology Promotion, Suwon, Gyeonggi 443-270, Republic of Korea

\section{T.-S. Shin}

Division of Food \& Nutrition, Chonnam National University, Gwangju 61186, Republic of Korea

\section{Tsukamoto}

Department of Applied Biological Chemistry, Iwate University, Morioka, Iwate 020-8550, Japan

\section{G. Chung}

Department of Biotechnology, Chonnam National University, Yeosu, Chonnam 550-749, Republic of Korea

J.-W. Suh

Division of Bioscience and Bioinformatics, Myongii University, Gyeonggi 449-728, Republic of Korea

*Correspondending authors

(J.-W. Suh: jwsuh@mju.ac.kr; G. Chung: chung@chonnam.ac.kr)

This is an Open Access article distributed under the terms of the Creative Commons Attribution Non-Commercial License (http://creativecommons org/licenses/by-nc/3.0/) which permits unrestricted non-commercial use, distribution, and reproduction in any medium, provided the original work is properly cited.
Keywords allergic reaction $\cdot \beta$-hexosaminidase $\cdot$ degranulation $\cdot$ RBL-2H3 Cells $\cdot$ soyasaponins

현대사회의 서구화된 식생활과 생활환경의 변화, 각종 환경 오 염 증가 그리고 유전적 요인 등의 복합적인 원인에 의해 알레 르기 질환이 해마다 증가하고 있다(Ebo 등, 2001; Alma 등, 2008). $\mathrm{IgE}$ 가 관여하여 일어나는 제 1 형 과민반응은 즉시형 알 레르기 반응으로 불리우며, 아토피 피부염, 천식, 알레르기 비 염 등을 포함하는 가장 흔한 만성 면역계 질환이다. 비만세포 는 대부분의 알레르기 질환에 중요한 역할을 하는 세포로 알려 져 있다. 알레르기 반응은 $\mathrm{IgE}$ 가 비만세포의 표면 수용체(highaffinity receptor for IgE, FcERI)와 결합되어 있어 알레르기 원 인물질인 항원이 재차 유입되게 되면 비만세포 표면의 고친화 성 $\mathrm{IgE}$ 수용체 $(\mathrm{Fc \varepsilon RI})$ 에 항원이 결합하게 된다. 이때 비만세포 가 활성화가 되면 비만세포의 탈과립이 유도되어 과립내 존재 하던 히스타민, 사이토카인 그리고 케모카인과 같은 알레르기 유발 물질들이 세포 밖으로 분비되어 알레르기 반응을 일으키 게 된다(Huang 등, 2008; Toshio, 2012).

그러므로 탈과립 억제를 통한 비만세포 활성화 조절은 알레르 기 반응의 예방과 치료에 중요한 자료로 활용될 수 있을 것이다. 콩은 우리나라뿐만 아니라 전세계적으로 다양한 전통 및 가 공식품으로 이용되고 있으며, 단백질, 지방 등의 함량이 높고 isoflavone 및 soyasaponin 같은 생리활성물질들이 다량 함유되 어 있다. 콩의 대표적 생리활성 물질로 isoflavone 이 많이 알 려졌으나, 최근 콩에 함유된 soyasaponin의 혈중 콜레스테롤 감 소효과, 항산화활성, 항바이러스, 간독성 물질제거, 항종양활성, 면역증진 효과 등 여러 생리활성 기능이 밝혀지면서 신규 식의 약 소재로 많은 주목을 받고 있다.

콩 종실에 포함된 soyasaponin은 품종, 재배연도, 재배지역 및 
성숙기에 따라서 건물 중 기준으로 $0.66 .5 \%$ 가 함유되어 있으며, 부위별로 볼 때 자엽에 $0.20 .3 \%$, 배아에 약 $2 \%$ 함유된 것으로 알려져 있다.

Soyasaponin은 비배당체(aglycone)인 soyasapogenol A, B, E 및 DDMP(2,3-dihydro-2,5-dihydroxy-6-methyl-4Hpyran-4-one)과 이들에 부착되는 당에 의하여 다양하게 분류 된다. Soyasaponin 은 크게 $\mathrm{A}, \mathrm{B}, \mathrm{E}$ 계열로 구분되며, $\mathrm{A}$ 계열을 $\mathrm{Aa}, \mathrm{Ab}, \mathrm{Ad}$, $\mathrm{Ae}, \mathrm{Af}$ 로, $\mathrm{B}$ 계열은 $\mathrm{DDMP}$ 가 부착된 $\alpha \mathrm{g}, \beta \mathrm{g}, \beta \mathrm{a}, \gamma \mathrm{g}, \gamma \mathrm{a}$ 와 $\mathrm{DDMP}$ 가 부착되지 않은 $\mathrm{Ba}, \mathrm{Bb}, \mathrm{Bb}, \mathrm{Bc}$ 로, $\mathrm{E}$ 계열은 $\mathrm{Bd}$ 와 $\mathrm{Be}$ 로 구분한다. 하지만, 학자들에 따라 조금씩 다르게 명명되기 도 한다.

A계열 soyasaponin은 종실의 배 부분에만 존재하고 항 영양적 요소로 콩가공식품의 쓴맛, 떫은맛 등의 불쾌한 맛을 나타내고 소화율을 감소시키는 원인으로 알려져 있다. B계열 soyasaponin 은 배와 자엽에 존재하고, 콩이 나타내는 대부분의 생리활성에 중요한 역할을 하는 것으로 알려져 있으며, B계열 soyasaponin 중에서도 DDMP 사포닌이 중요하게 평가되고 있다(Yang 등, 2015).

콩 배아에 다량 함유되어있는 isoflavone, soyasaponin, 불포 화지방산이 떫고 쓴맛과 더불어 콩 특유의 비린내를 유발, 기 호성을 저하시키므로 식품제조업체에서는 목적에 따라 종피와 배아를 제거하고 자엽으로만 가공제품을 생산하기도 한다. 제품 생산과정에서 발생되는 콩 껍질 및 배아와 같은 부산물은 가축 의 사료나 퇴비 등으로 활용되고 있으나 그 이용도가 극히 제 한적이어서 대부분은 폐기물로 처리되어 추가적 비용을 발생시 키고, 각종 환경오염을 유발하여, 사회적인 문제점으로 지적되 고 있다.

따라서, 콩제품의 제조과정에서 발생하는 부산물 또는 폐액 등에서 isoflavone 또는 soyasaponin을 분리하여 산업소재화 하 고자 하는 각종 연구가 수행되었으나, 이 두 물질을 동시에 분 리할 수 있는 방법을 제시하지는 못하였다.

따라서, 본 연구에서는 콩의 가공과정에서 발생되는 종피와 배아 등의 혼합 부산물로부터 배아를 별도로 분리하고, 이로부 터isoflavone과 soyasaponin을 동시에 분리 할 수 있는 기술을 연구, 개발하였으며, 분리된 soyasaponin 4종( $\mathrm{Aa}, \mathrm{Ab}, \beta \mathrm{g}$, $\mathrm{DDMP}$ )에 대한 생리활성 연구와 알레르기 반응에 중요한 역할 을 하는 비만세포의 탈과립 억제 효과를 확인하였다.

본 실험에 사용한 4종의 soyasaponin은 잘 건조된 콩에서 껍 질을 제거한 후 hypocotyl을 분리하여 분말화하였다. hypocotyl 분말 $20 \mathrm{~g}$ 에 $80 \%$ methanol $200 \mathrm{~mL}$ 을 가하고 24 시간 동안 실 온에 방치하여 saponin을 추출하였다. 추출물은 감압하에서 회 전농축기를 사용하여 완전히 건조하고 이를 다시 증류수 $200 \mathrm{~mL}$ 과 butanol $200 \mathrm{~mL}$ 혼합용액에 완전히 녹여서 24시간 방치하였 다. Butanol층을 물층에서 분리하여 회전농축기를 이용하여 완 전히 건조하였다. 이들 시료는 $30 \%$ acetonitrile에 용해하여 50 $\mathrm{mL}$ 로 정용하고 $0.20 \mu \mathrm{m}$ membrane filter로 여과 후 highperformance liquid chromatography (HPLC) 시료로 사용하였다.

HPLC는 Shimadzu LC-20AD pump, CTO-20AC oven, Sil20AC auto-sampler, SPD-M20A photodiode array detector, CBM-20A system controller, FRC-10A fraction collector, LC Workstation software로 구성하여 saponin을 분리하였다. column 은 ODS 계열의 Shim-pack Phenomenex $(21.20 \times 250 \mathrm{~mm})$ 을 사용하였다. 이동상은 A용액 acetonitrile과 B용액(30:70= acetonitrile: $0.025 \%$ trifluoroacetic acid)를 사용하여 B용매를 0
분에서 $90 \%$ 으로 시작하여 50 분에 $50 \%$ 으로 감소시키고 60 분까 지 $50 \%$ 를 유지한 후 60 분에서 61 분까지 $90 \%$ 로 증가시켜 15 분간 유지하여 column을 $95 \% \mathrm{~B}$ 용액에 평형화였다. 이동상 유 속은 $7.0 \mathrm{~mL} / \mathrm{min}$ 로 조절하고 injection volume $200 \mu \mathrm{L}$ 주입하 며 PDA detector의 파장은 $209 \mathrm{~nm}$ 를 사용하며 완전분리 유무 는 SPD-M20A photodiode array detector를 이용하여 확인하였다.

Saponin 조성물의 HPLC 분석은 Shimadzu LC-20AD pump, CTO-20AC oven, Sil-20AC auto-sampler, SPD-M20A photodiode array detector, CBM-20A system controller, FRC-10A fraction collector, LC Workstation software로 구성하여 saponin을 분리하 였다. Column은 ODS 계열의 Shim-pack Phenomenex $(21.20 \times 250$ $\mathrm{mm})$ 을 사용하였다. 이동상은 A용액 acetonitrile과 B용액(30:70= acetonitrile: $0.025 \%$ trifluoroacetic acid)를 사용하여 B용매를 0 분 에서 $90 \%$ 으로 시작하여 50 분에 $50 \%$ 으로 감소시키고 60 분까지 $50 \%$ 를 유지한 후 60 분에서 61 분까지 $90 \%$ 로 증가시켜 15 분간 유지하여 column을 $95 \%$ B용액에 평형화였다. 이동상 유속은 $7.0 \mathrm{~mL} / \mathrm{min}$ 로 조절하고 injection volume $200 \mathrm{~mL}$ 주입하며 PDA detector의 파장은 $209 \mathrm{~nm}$ 를 사용하며 완전분리 유무는 SPDM20A photodiode array detector를 이용하여 확인하였다(Fig. 1).

분리된 4종의 soyasaponin의 RBL-2H3 세포에서 세포 생존율 및 증식에 미치는 영향을 확인하기 위해 MTT((3-(4,5-dimethylthiazol-2-yl)-2,5-diphenyl-tetrazolium bromide) assay를 실시하였 다. RBL-2H3 세포를 96 well plate에 $1 \times 10^{4} /$ well 세포수로 분주 하여 soyasaponin 4종을 각각 농도별 $(0,3.125,6.25,12.5,25$, $50,100 \mathrm{mM}$ )로 24 시간 처리하여 세포 생존율을 측정한 결과 soyasaponin 4종 모두 모든 농도에서 세포독성이 관찰되지 않았 다(Supplementary Fig. 1). $\beta$-Hexosaminidase는 천식이나 알레르 기 비염과 같은 알레르기 반응에 의해 비만세포나 호염구의 과 립 안에 저장되어 있던 히스타민을 세포 밖으로 분비하므로 탈 과립의 측정 지표로 많이 사용되며 알레르기 억제물질의 생리활 성 측정에 유용하게 이용되고 있다(Galli 등, 2005; Xiax 등, 2014). 항원-항체 반응에 의한 $\beta$-hexosaminidase 분비에 미치는 영향을 확인하기 위하여 ATCC (American Type Culture Collection, USA)에서 구입한 RBL-2H3 세포를 $15 \%$ Fetal Bovine Serum을 포함하는 $\mathrm{MEM}$ 배지를 넣고 $37^{\circ} \mathrm{C} 5 \% \mathrm{CO}_{2}$ 조건에서 배양하였 다. $2 \times 10^{5} / \mathrm{well}$ 의 세포수로 24 시간 배양 후 상등액을 제거하고 anti-DNP $\operatorname{IgE}(25 \mathrm{ng} / \mathrm{mL})$ 로 4시간 동안 감작한 후 PIPES 완충 용액 $(25 \mathrm{mM}$ PIPES, $119 \mathrm{mM} \mathrm{NaCl}, 5 \mathrm{mM} \mathrm{KCl}, 1 \mathrm{mM} \mathrm{CaCl} 2$, $0.4 \mathrm{mM} \mathrm{MgCl}, 40 \mathrm{mM} \mathrm{NaOH}, 5.6 \mathrm{mM}$ glucose, $0.1 \% \mathrm{BSA}$ ) 으로 세척하고 10 분 동안 반응시켰다. soyasaponin을 25,50 , 그 리고 $100 \mathrm{mM}$ 농도로 20 분간 처리 후 $50 \mathrm{ng} / \mathrm{mL} \mathrm{DNP-BSA}$ 를 20 분간 반응시킨 후 얼음 위에 두어 반응을 정지시켰다. 탈과립 에 의해 세포 밖으로 분비된 $\beta$-hexosaminidase 양을 측정하기 위 해 96 well plate에 상등액과 $1 \mathrm{mM}$ P-니트로페닐-아세틸- $\beta-\mathrm{D}-$ 글 루코사미니드를 동량으로 넣고 1 시간 동안 반응시킨 후 $0.1 \mathrm{M}$ citrate buffer를 넣어 반응을 종결시켰다. $\beta$-Hexosaminidase 분비 에 미치는 soyasaponin의 효과를 $\mathrm{IC}_{50}$ 값으로 확인해 본 결과 soyasaponin $\mathrm{Aa}$ 는 $94.01 \mathrm{mM}$, soyasaponin $\mathrm{Ab}$ 는 $54.36 \mathrm{mM}$, soyasaponin $\mathrm{bg}$ 는 $56.66 \mathrm{mM}$, soyasaponin DDMP는 $38.15 \mathrm{mM}$ 로 soyasaponin 4종 중 soyasaponin DDMP가 비만세포의 탈과 립 억제 효능이 가장 우수한 것으로 나타났다. 대조군으로 사용 한 ketotifen fumarate (Morikawa 등, 2010; Hong과 Oh, 2012) 의 $\mathrm{IC}_{50}$ 값은 $38.77 \mathrm{mM}$ 로 나타났다.

Soyasaponin의 각 농도별 억제율은 Table 1에 나타냈으며 농 


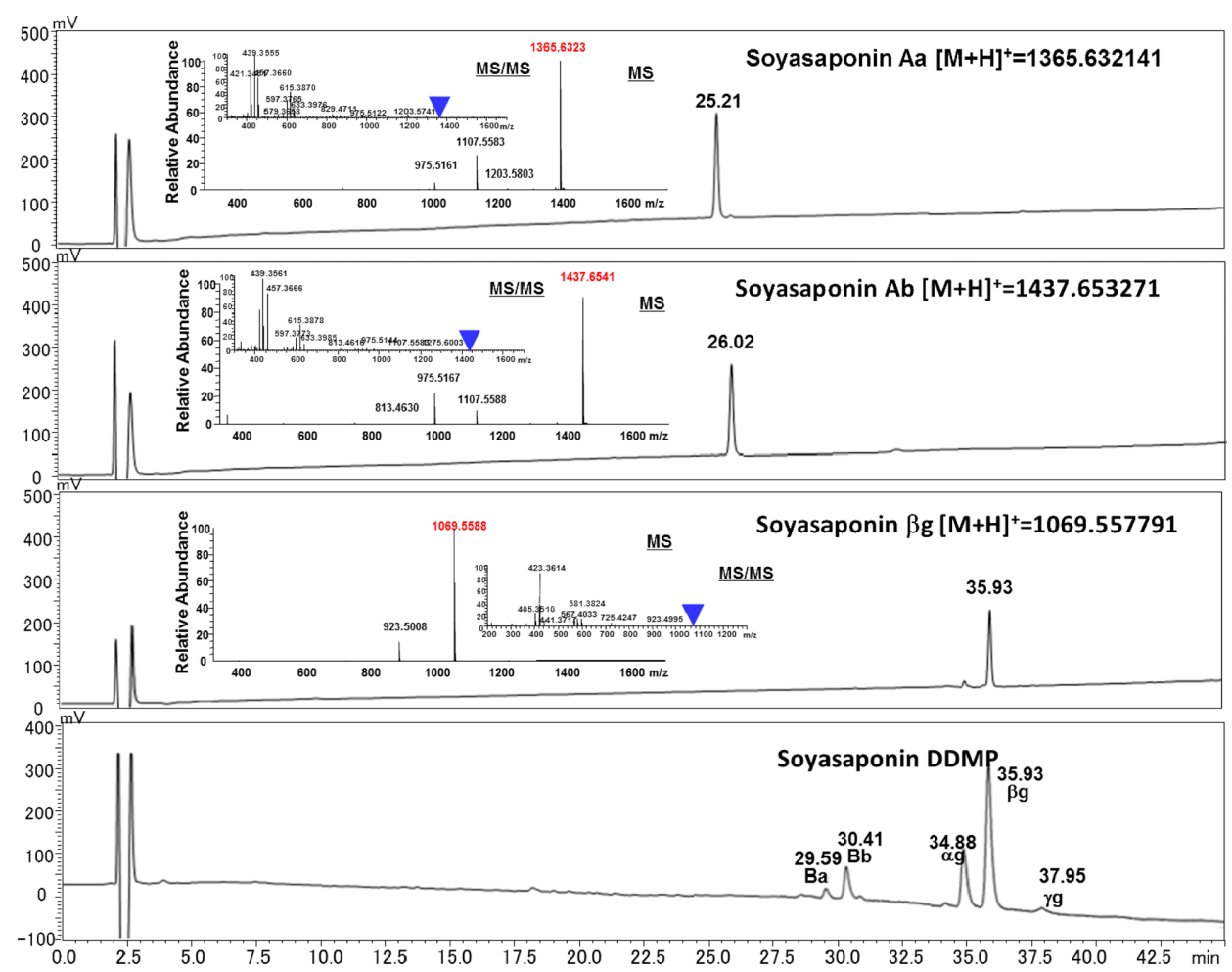

Fig. 1 Chromatogram of soybean hypocotyl; solid peaks present fraction cuts. 1, Aa; 2, Ab; 3, bg; 4, DDMP.

도 의존적으로 억제 효과를 보였다. 또한 알레르기 즉시반응의 지표인 탈과립에 대한 억제효과를 확인하기 위해 탈과립 후 유 리되는 대표물질인 histamine 분비능을 측정하였다. $\beta$ Hexosaminidase assay 측정과 동일한 방법으로 histamine 분비 를 유도한 후 상등액 $25 \mathrm{~mL}$ 와 $0.1 \mathrm{~N} \mathrm{HCl} 22.5 \mathrm{~mL}, 60 \%$ $\mathrm{HClO}_{4} 2.5 \mathrm{~mL}$ 를 혼합하여 $2,000 \mathrm{rpm}$ 에서 10 분간 원심분리 한 후 상등액 $40 \mathrm{~mL}$ 를 취해 $5 \mathrm{~N} \mathrm{NaOH} 25 \mathrm{~mL}, n$-butanol 500 $\mathrm{mL}$ 와 $\mathrm{NaCl} 0.06 \mathrm{~g}$ 을 넣고 진탕하여 원심 분리하였다. 분리된 Butanol층에 $0.1 \mathrm{~N} \mathrm{HCl}$ 용액과 $\mathrm{n}$-heptan을 넣어 원심분리를 통 해 물층을 얻고, 얻어진 물층에 다시 $1 \mathrm{~N} \mathrm{NaOH}$ 와 OPT $(o-$ phthaldialdehyde) 용액을 혼합하여 $37^{\circ} \mathrm{C}$ 에서 반응시킨 후 $3 \mathrm{~N}$ $\mathrm{HCl}$ 용액을 넣고 반응하여 fluorometer (Victor ${ }^{3}$, perkin Elmer, USA)를 통해 $360 \mathrm{~nm}$ (excitation)와 $450 \mathrm{~nm}$ (emission)에서 형 광값을 측정하였다(Kwon과 Song, 2012). 4종의 soyasaponin이 histamine 분비에 미치는 영향을 확인해 본 결과 soyasaponin
$\mathrm{Aa}$ 는 $25 \mu \mathrm{M}$ 에서 $62.42 \%, 50 \mathrm{mM}$ 에서 $62.95 \%, 100 \mathrm{mM}$ 에서 $69.18 \%$ 의 억제 효능을 보였고 soyasaponin $\mathrm{Ab}$ 는 $25 \mathrm{mM}$ 에서 $2.15 \%, 50 \mathrm{mM}$ 에서 $58.85 \%, 100 \mathrm{mM}$ 에서 $70.83 \%$ 의 억제 효능 을 보였다. 또한 soyasaponin $\mathrm{bg}$ 는 $25 \mathrm{mM}$ 에서 $1.53 \%, 50$ $\mathrm{mM}$ 에서 $57.94 \%, 100 \mathrm{mM}$ 에서 $76.52 \%$ 의 억제 효능이 있었고 soyasaponin DDMP 의 경우 $25 \mathrm{mM}$ 에서 $73.8 \%, 50 \mathrm{mM}$ 에서 $74.79 \%, 100 \mathrm{mM}$ 에서 $79.40 \%$ 로 억제 효과를 보였고 농도의존 적으로 유의성 있는 결과를 나타내었다. 그리고 $\beta$-hexosaminidase assay 효능과 마찬가지로soyasaponin 4종 중 soyasaponin $\mathrm{DDMP}$ 가 histamine 분비 억제 효과 또한 가장 우수한 것으로 나타났다(Fig. 2). 대조군으로 사용한 ketotifen fumarate는 25 $\mathrm{mM}$ 에서 $47.34 \%, 50 \mathrm{mM}$ 에서 $77.91 \%, 100 \mathrm{mM}$ 에서 $81.50 \%$ 로 나타났다. 이러한 결과를 통하여 soyasaponin 4종은 RBL-2H3 세포에서 세포독성이 없으며 $\beta$-hexosaminidase와 histamine 분 비를 억제함으로써 항알레르기 효능을 가지는 것으로 사료된다.

Table 1 The inhibitory effect of soyasaponin on release of $\beta$-hexosaminidase from RBL-2H3 cells

\begin{tabular}{llcc}
\hline & & \multicolumn{2}{c}{ Inhibition $(\%)$} \\
\cline { 2 - 4 } & $25 \mu \mathrm{M}$ & $50 \mu \mathrm{M}$ & $100 \mu \mathrm{M}$ \\
\hline Soyasaponin $\mathrm{Aa}$ & $21.13 \pm 2.10$ & $26.62 \pm 6.81^{* *}$ & $53.21 \pm 3.68^{* *}$ \\
Soyasaponin $\mathrm{Ab}$ & $28.49 \pm 1.72^{*}$ & $54.11 \pm 2.19^{* *}$ & $74.89 \pm 4.71^{* *}$ \\
Soyasaponin $\beta \mathrm{g}$ & $29.51 \pm 2.72^{* *}$ & $44.26 \pm 8.06^{* * *}$ & $79.59 \pm 1.46^{* * *}$ \\
Soyasaponin DDMP & $43.68 \pm 9.39^{* * *}$ & $56.35 \pm 4.23^{* * *}$ & $75.26 \pm 5.17 * * *$ \\
Ketotifen & $41.44 \pm 3.50^{* * *}$ & $68.17 \pm 3.70^{* * *}$ & 54.36 \\
\hline
\end{tabular}

Data are expressed as mean $\pm \mathrm{SD}$, where $* p<0.05, * * p<0.01, * * * p<0.001$ was considered statistically significant. 

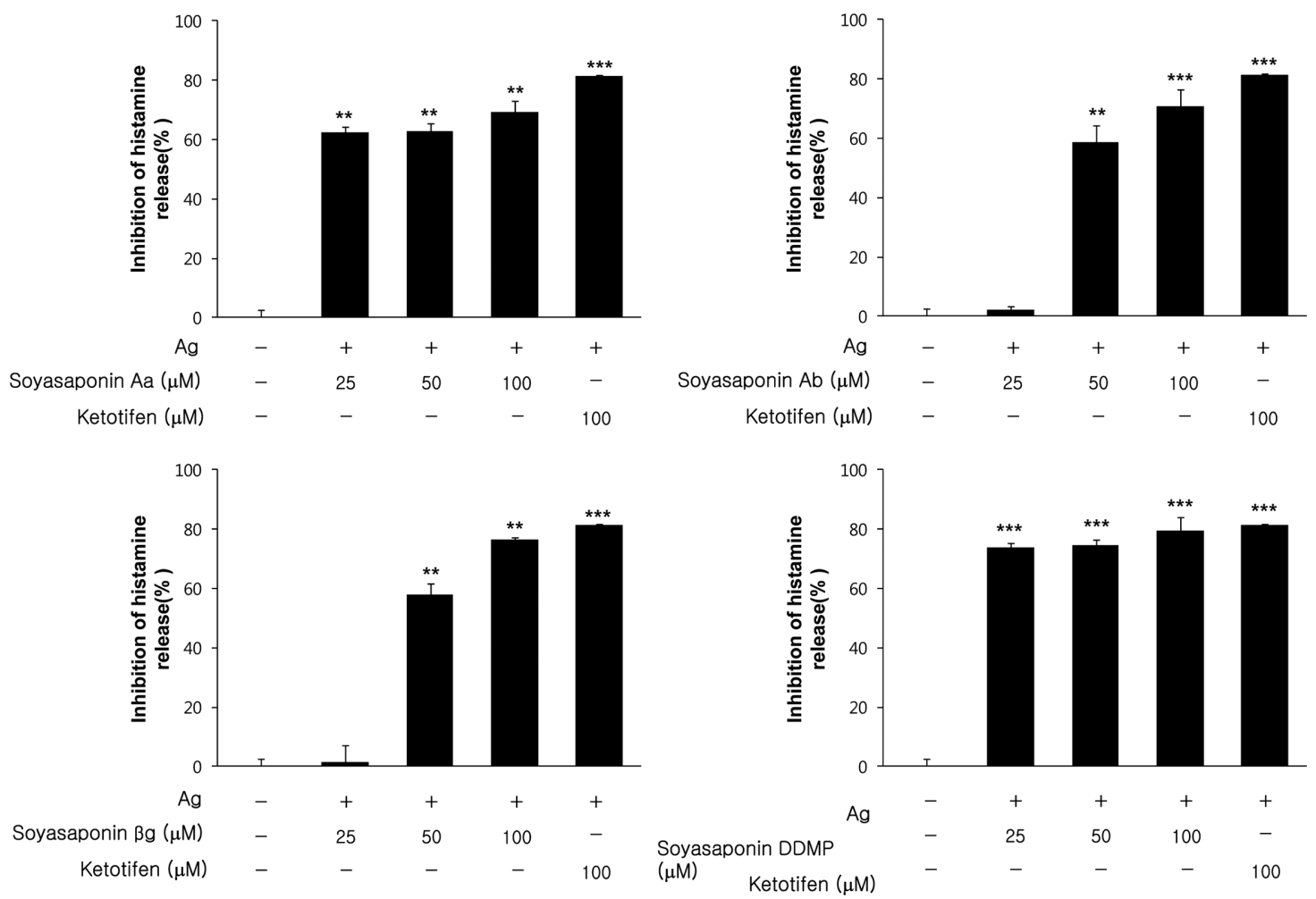

Fig. 2 Effect of soyasaponin on the histamine release in RBL-2H3 cells. Cells were grown on 24 well plates $\left(2 \times 10^{5}\right.$ cells/well $)$ and sensitized overnight with $25 \mathrm{ng} / \mathrm{mL}$ of DNP-specific IgE. The IgE-sensitized cells were pre-incubated and then exposed to the compounds for 1hr. After incubation, cells were stimulated with $50 \mathrm{ng} / \mathrm{mL}$ of DNP-BSA for $1 \mathrm{hr}$. The fluorescence intensity was measured with excitation at $360 \mathrm{~nm}$ and emission at $450 \mathrm{~nm}$ with a fluorometer. Data are expressed as mean $\pm \mathrm{SD}, * p<0.05, * * p<0.01, * * * p<0.001$ was considered statistically significant.

\section{초 록}

본 연구에서는 콩의 배축(hypocotyls)에서 분리된 4종의 soyasaponin (Aa, Ab, bg, DDMP)에 대해 RBL-2H3 세포를 이용하여 항알레 르기 활성을 확인하고자 하였다. RBL-2H3 세포에서 soyasaponin 화합물들의 세포독성을 확인해 본 결과, 4종 모두 세포독성이 없 었고 $\beta$-hexosaminidase assay를 통해 비만세포의 탈과립 억제 효 능을 확인해 본 결과 대조군으로 사용한 Ketotifen fumarate $\left(\mathrm{IC}_{50}: 38.77 \mathrm{mM}\right)$ 와 비교하여 4종 모두 $\beta$-hexosaminidase 억제 효능이 있는 것을 확인하였다. 또한, soyasaponin 화합물들은 RBL-2H3 세포에서 탈과립 후 유리되는 대표적인 물질인 histamine의 분비 억제에도 효능이 있음을 확인하였고 이 중 Soyasaponin DDMP가 가장 효능이 우수한 것으로 판단된다.

Kewords 베타-헥소사미니다아제 · 소야사포닌 · 알레르기 반응 · 탈과립화 · RBL-2H3 세포

감사의 글 본 연구는 농촌진흥청 연구사업 (세부과제번호: PJ01128901)의 지원에 의해 이루어진 것임.

\section{References}

Alma JN, Ferdi E, Leon MK, Johan G, Frans PN, and Frank AR (2008) Mechanisms of allergy and asthma. Eur J Pharmacol 585, 354-60.
Ebo DG and Strvens WJ (2001) IgE-mediated food allergy-extensive review of the literature. Acta Clin Belg 56, 234-47.

Galli SJ, Nakae S, and Tsai M (2005) Mast cells in the development of adaptive immune responses. Nat Immunol 6, 135-42.

Hong SS and Oh JS (2012) Inhibitors of antigen-induced degranulation of RBL-2H3 cells isolated from wheat bran. J Korean Soc Appl Biol Chem $\mathbf{5 5}, 69-74$.

Huang H, Tong X, Deng H, Fu L, and Zhang R (2008) Inhibition of the antigen-induced activation of RBL-2H3 cells by gab2 siRNA. Cell Mol Immunol 5, 433-8.

Kwon HS and Song CH (2012) Effect of Scutellaria barbata pharmacopuncture extract on degranulation and inflammatory mediator release in RBL-2H3 cells. Korean J Acupunct 29, 406-20.

Morikawa T, Xu F, Matsuda H, and Yoshikawa M (2010) Structures of novel norstilbene dimer, longusone $\mathrm{A}$, and three new stilbene dimmers, longusols $\mathrm{A}, \mathrm{B}$, and $\mathrm{C}$, with antiallergic and radical scavenging activities from Egyptian natural medicine Cyperus longus. Chem Pharm Bull 58, 1379-85.

Toshio T (2012) Efficacy of Flavonoids for patients with Japanese Ceder Pollinosis. Current Insights in Pollen Allergens 103, 1-22.

Xiax S, Jiang J, Shim DW, Kim TK, Kang TB, and Lee KH (2014) Antiallergic effect of ethanolic extract of Flos Sophora japonica L. on $\mathrm{Ca}^{++}$ ionophore stimulated murine RBL-2H3 cells. J Korean Soc Food Sci Nutr 43(3), 349-54.

Yang SH, Ahn EK, Lee JA, Shin TS, Tsukamoto C, Suh JW et al. (2015) Soyasaponins $\mathrm{Aa}$ and $\mathrm{Ab}$ exert an anti-obesity effect in 3T3-L1 adipocytes through downregulation of PPAR $\alpha$. Phytother Res 29(2), 281-7. 